\title{
The Indonesian Electronic Information and Transactions Within Indonesia's Broader Legal Regime: Urgency for Amendment?
}

\author{
Travis Tio Pratama Waluyo, Elizabeth Calista, Danielle Putri Ratu, \\ Tasya Safiranita Ramli, Ahmad M. Ramli \\ Center for Cyber Law and Digital Transformation Studies, Faculty of Law, \\ Universitas Padjadjaran Bandung \\ tasva safiranita@vahoo.com
}

\begin{abstract}
Cyberspace is the interdependent network of information technology infrastructures such as the internet, telecommunications networks, and computer systems. Meanwhile, Indonesia's Law Number 11 of 2008 and its amendment through Indonesian Law Number 19 of 2016 governing cyberspace have been viewed to contradict and infringe other areas of law, such as protection of press or freedom of expression. Hence, this study seeks to identify the controversies and problems regarding the law deemed urgent for amendment. Further, this study creates recommendations so the government may amend electronic information policy more fairly and efficiently. This study uses a judicial normative and comparative approach. This research tries to analyze the existing regulations and the implementation and compare Indonesia's cyberspace regulation with other States'. This study finds that Articles 27(3) and 28(2) of the law criminalize defamation and hate speech in an overly broad manner and that Article 40(2)(b) allows the government to exercise problematic censorship. As a result, they have infringed the freedom of the press and general freedom of expression in practice. In response to this, this study compares similar provisions from other States and recommends amendment the articles to become narrower and more clearly defined.
\end{abstract}

Keywords: cyber law; Indonesian electronic information and transaction law; freedom of the press; freedom of expression; legal reform.

\begin{abstract}
ABSTRAK
Cyberspace adalah jaringan infrastruktur teknologi informasi yang saling bergantung seperti internet, jaringan telekomunikasi dan sistem komputer. Sementara itu, Undang-Undang Nomor 11 Tahun 2008 dan melalui perubahannya pada Undang-Undang Nomor 19 Tahun 2016 tentang Informasi dan Transaksi Elektronik terkait dinilai bertentangan dan melanggar perlindungan pers atau kebebasan berekspresi. Oleh karena itu, penelitian ini berusaha untuk mengidentifikasi kontroversi dan permasalahan mengenai undang-undang yang dianggap mendesak untuk diubah. Selanjutnya, penelitian ini memberikan rekomendasi agar undang-undang tersebut dapat memuat pengaturan mengenai informasi elektronik secara lebih adil dan efisien. Penelitian ini mennggunakan pendekatan yuridis normatif dan komparatif. Penelitian ini mencoba untuk menganalisa regulasi yang ada dan implementasinya serta membandingkan regulasi cyberspace di Indonesia dengan negaranegara lain. Studi ini menemukan bahwa Pasal 27(3) dan 28(2) undang-undang tersebut telah mengakibatkan kriminalisasi terhadap terduga pelaku pencemaran nama baik dan ujaran kebencian terlalu luas dan Pasal 40(2)(b) memungkinkan pemerintah untuk melakukan sensor yang problematik. Dalam praktiknya, hal ini telah melanggar kebebasan pers dan kebebasan berekspresi secara umum. Menanggapi hal ini, penelitian ini membandingkan ketentuan serupa dari negara-negara lain dan merekomendasikan perubahan pada pasal-pasal tersebut agar lebih jelas dan cakupannya lebih sempit.
\end{abstract}

Kata Kunci: hukum siber; hukum informasi dan transaksi elektronik Indonesia; kebebasan pers; kebebasan berekspresi; reformasi hukum. 


\section{INTRODUCTION}

Since its conception in the late 1990s, The regulation of the internet has always been a topic full of conflict and controversy. While some argue its regulation is necessary and others argue it should be left well enough alone. The reality is that the regulation of online activity exists. The circumstances in Indonesia are no exception to this general premise. As the primary instrument regulating internet-related activity, Law Number 11 of 2008 on the Electronic Information and Transactions (hereinafter EIT Law) continues to be debated in public dialogue. The amendment of Law Number 11 of 2018 on The Electronic Information and Transactions, which is The Law Number 19 of 2019 on the revision of The Law number 11 of 2018 on The Electronic Information and Transaction, has not stopped legal experts', media outlets,' and society's critics.

A driving force for this controversy is the concerns revolving around abuse of power, censorship, and limitations of rights such as freedoms of expression and freedom of the press. ${ }^{1}$ In the general context of this study, the core item on the aforementioned list is the freedom of expression: a concept that might be loosely defined as the principle that supports the freedom to articulate opinions and ideas without fear of retaliation, censorship, or legal sanction. Internationally, States have widely recognized this freedom in both the Universal Declaration of Human Rights and the International Covenant of Civil and Political Rights. Both provisions enshrine the right to seek, receive and impart information regardless of its media. In Indonesia, there are multiple layers to this in the legal regime, most fundamentally observed in Articles 28 and $28 \mathrm{E}$ (3) of the Indonesian constitution. It is further enshrined in Article 25 of the Indonesian Law Number 39 of 1999 on Human Rights. The aforementioned controversy that the authors seek to highlight here is driven by concerns that

1 Marwadianto Marwadianto, "Hak Atas Kebebasan Berpendapat Dan Berekspresi," Jurnal HAM 11, no. 1 (2020): 1-4. the implementation of the EIT law contradicts the guarantees of the above provisions, hence impeding freedom of expression.

Although reading the EIT law's text may not prima facie reflect such implementation-related issues impeding the above freedom, opinions from cyber-security research groups, digital rights activists, and public discussion forums all contain concern over the implementation of certain policies provisions in the law. This has occurred to the point that President Joko Widodo has issued a statement calling for the EIT law's content and enforcement to be put under evaluation and reform. ${ }^{2}$

Prior to analyzing regulations over the internet, it is worth looking at the underlying debate to set the scene for the author's analysis: the contention between regulating access to and content within the internet against the attached human rights relating to equal access and freedom of expression. While this object of debate is not entirely novel, in an age where the internet is such a powerful and global tool, said debate remains undoubtedly relevant. We have seen this topic discussed extensively in the forums of American, African, and European State coalitions as well as even the United Nations, both together as well as separately. ${ }^{3}$

To reference some of these forums more specifically, the authors draw to attention this was discussed by the Office of the Special Rapporteur for Freedom of Expression InterAmerican Commission on Human Rights in 2013 in a document which highlighted the internet as an unprecedented development for expression, one that required both protection as well as cautious regulation. ${ }^{4}$ Citing a report to the United

2 CNN Indonesia, "Jokowi: Kalau Picu Ketidakadilan Hapus Pasal Karet UU ITE," CNN Indonesia, accessed April 20, 2021, https://www.cnnindonesia.com/ nasional/20210216092243-32-606711/jokowi-kalaupicu-ketidakadilan-hapus-pasal-karet-uu-ite.

3 OSCE, Joint Declarations of the Representatives of Intergovernmental Bodies to Protect Free Media and Expression, ed. Adeline Hulin (Vienna: OSCE The Representative on Freedom of the Media, 2013), 22.

4 Inter-American Commission on Human Rights, Special 
Nations General Assembly, they called the internet something which "like no other means of communication before, has allowed individuals to communicate instantly and at a low cost, and has had a dramatic impact on journalism and the way in which we share and access information and ideas." ${ }^{5}$ The report goes on to say that "... steps should be taken to progressively promote universal access not only to infrastructure but also the technology necessary for its use and to the greatest possible amount of information available on the Internet..." and "that has made the Internet a perfect medium for growing the democratic, open, plural and expansive exercise of freedom of expression should be taken into account when establishing any measure that could impact upon it."

These discussions, however, do not conclude that such freedoms are equal to a non-regulated internet. While the discussions go to great lengths in order to cite documents enshrining the freedom of expression (both offline and online; such as the Universal Declaration of Human Rights, The International Covenant on Civil and Political Rights as well as the 1948 United Nations Human Rights Committee Resolution), it is clear that they also note that those rights have limitation. What must be emphasized is how those limitations can rightfully occur; for example, a prominent and widely recognized test is that any limitation or restriction must be determined by law, have a legitimate purpose, and adhere to strict confines of the principle of need and proportionality. ${ }^{7}$ These are also enshrined and recognized in the Siracuse Principles, a concept the authors seek to investigate in our discussion as applied in

Rapporteur on Freedom of Expression, 2013.

5 United Nations General Assembly, "Report of the Special Rapporteur on the Promotion and Protection of the Right to Freedom of Opinion and Expression," Human Rights Council 17, no. 27 (2011): 4-22.

6 Inter-American Commission On Human Right, Freedom of Expression and the Internet (Finland: Organization of American States, 2013), 20.

7 Anak Agung Ayu Nanda Saraswati, "The Need To Protect Freedom Of Expression On The Internet Through A Human Rights-Based In," ASEAN Journal of Legal Studies 2, no. 1 (2019): 54-69.
Indonesia. When such limitation is provided properly, the regulation of the internet can prevent harmful expressions without infringing on the State's obligation to protect human rights. For example, expressions such as child pornography, the systematic spread of hatred, public incitement of genocide, provocations towards widespread discrimination, and violence are all expressions that can occur on the internet, which governments must not leave alone. ${ }^{8}$ The UN Special Rapporteur on the promotion and protection of the right to freedom of opinion and expression provided a loose classification of expressions that must be excluded from protection: ${ }^{9}$

- expressions which constitute violations of international law and can be criminalized;

- $\quad$ expressions that cannot be criminalized but which can justify civil restrictions and demands; and

- expressions that do not provide criminal or civil sanctions but still cause concern in terms of tolerance, courtesy, and respect for other parties.

According to the World Bank, Indonesia had more than $53 \%$ of its population (around $144,967,500$ people) asinternetusers. ${ }^{10}$ As acountry with more of its population using the internet than those who do not, it is undoubtedly relevant to analyze whether or not its government has upheld the above human rights and proper methods of their limitation in regulating the problematic forms of expression also aforementioned. In 2018, the freedom on the Net report from Freedom House categorized Indonesia as partially free in relation to its cyberspace. ${ }^{11}$ Studies have taken this to indicate that problems such as unequal access, unjust filtering and censorship, criminalized users

\footnotetext{
$8 \quad$ Ibid., 58-59.

9 Ibid, 58-59.

10 World Bank, "Individuals Using the Internet (\% of Population) - Indonesia," The World Bank, accessed November 26, 2021, https://data.worldbank.org/ indicator/IT.NET.USER.ZS?locations=VN.

11 Freedom House, "Freedom on the Net 2018: Indonesia," Freedom House, accessed November 26,2021, https://freedomhouse.org/report/freedom-net/ freedom-net-2018.
} 
of the internet, and other issues related to freedom on the internet still prevail. ${ }^{12}$

In this study, the authors will try to analyze two research questions. First, how does the Indonesian government currently implement the EIT Law in relation to defamation and hate speech? Second, how has the law potentially impacted the statutory right to freedom of expression and freedom of the press? This study will also provide additional recommendations on whether the amendment is needed or not. Unfortunately, it has been found that the law has been broadly regulating defamation and hate speech while allowing the government to conduct censorship power. The authors further recommend for the law to be amended.

\section{METHODOLOGY}

This writing uses a normative juridical method with a qualitative approach. This approach is necessary to the aim of this writing to provide a juridical argument when there is an ambiguity within the conflict of norms. It is performed through comparative case law studies that aim to overcome or resolve related human rights struggles by considering the application of human rights-related norms in law practice. ${ }^{13}$ The authors collected the data through secondary materials from online literature through documentary study consisting of primary, secondary, and tertiary legal materials.

The primary legal materials used in this writing include the 1945 Constitution of the Republic of Indonesia, the Indonesian Law Number 39 of 1999 on Human Rights, the Indonesian Law Number 11 of 2008 on the Electronic Information and Transactions as well as the Law Number 19 of 2016 on the Amendment to Law Number 11 of 2008 on Electronic Information and Transactions, the Indonesian Criminal Procedure Code, and the

12 ELSAM Team, Buku Saku Kebebasan Berekspresi Di Internet, Seri Internet Dan HAM (Jakarta Selatan: Lembaga Studi dan Advokasi Masyarakat [ELSAM], n.d.), 53-82.

13 Kristin Reed and Ausra Padskocimaite, The Right Toolkit: Applying Research Methods in the Service of Human Rights (human rights center university of california, Berkeley school of law, 2012), 10.
Law Number 40 of 1999 on the press, in the context of their relation to the EIT law and its amendment. The secondary legal materials are supporting materials such as books, journals, papers, and other electronic literature obtained through online platforms. In addition to this, the above is also put into context with the help of tertiary research and legal materials, such as relevant dictionaries, legal journals, and other articles that can be applied appropriately.

The present analysis will attempt to describe, interpret, and contextualize certain concepts, specifically in relation to internetbased activity, such as access to the internet and social media expression and the aforementioned Indonesian laws and regulations that regulate and accommodate it. Moreover, it seeks to observe the EIT law in concreto; whether or not the law does positively solve the issues of preventing conflicts in cyberspace as well as providing a sense of security, justice, and legal certainty for users and providers of information technology through its regulatory contents. ${ }^{14}$ By looking at the materials above, the authors seek to search for and identify relevant facts on whether or not EIT Law is consistent with Indonesian human rights laws if the provisions facilitate impediment of human rights. ${ }^{15}$

\section{DISCUSSION/ANALYSIS}

\section{A. Cyber Law as a Concept: Definition and Limitations}

Generally, cyber law refers to laws relating to cyberspace (internet) which sometimes is also referred to as the Law of the Internet. ${ }^{16}$ Pavan Duggal defines cyberlaw as a general term that refers to all legal aspects and governance of the Internet and the World Wide Web. ${ }^{17}$

14 Amiruddin and Zainal Asikin, Pengantar Metode Penelitian Hukum, Revisi. (Jakarta: Raja Grafindo Persada, 2018), 125.

15 Bambang Sunggono, Metodologi Penelitian Hukum, Cetakan ke. (Jakarta: Rajawali Pers, 2015), 91.

16 Nandang Sutrisno, "Cyberlaw: Problem Dan Prospek Pengaturan Aktivitas Internet," Jurnal Hukum IUS QUIA IUSTUM 8, no. 16 (2001): 30-41.

17 Tasya Safiranita Ramli et al., "Prinsip-Prinsip 
The term cyber was first introduced by Norbert Wiener, who defined the term cybernetics as "control and communication in the animal and the machine." This served as the foundation for the concept of cyberspace as a space resulting from humans' capability to interface with machines. Based on it, the term cyber continues to evolve. Many jurisdictions provide their own" thoughts on cyber, for example, In the U.S., cyberspace is defined as "the interdependent network of information technology infrastructures," which "includes the Internet, telecommunications networks, computer systems, and embedded processors and controllers in critical industries." Similar definition can also be found in Germany which defines cyberspace as "the virtual space of all IT systems linked at data level on a global scale."

As time goes by, the use of cyberspace has gained popularity in many aspects of human life. ${ }^{18}$ Because of the internet, we can now trade online, pay bills, play games, carry out banking activities and pave new ways for individuals, businesses, and the government to communicate. ${ }^{19}$

In practice, however, these innovative activities do not always run smoothly. The misuse of technology in cyberspace to impede the rights and safety of others has led to an urgency to enact and implement cyber laws. The most evident misuse is the 'new' proliferation of 'old' crimes such as illegal gambling, fraud, the spread of dangerous misinformation (hoaxes), hate speech, or distribution of illegal materials (e.g., drugs and pornography). With the development of cyberspace, a new platform also becomes a place to manifest rights such as online democracy and politics, equal opportunity - access to information, freedom of expression, and speech. In the same

Cyber Law Pada Media Over The Top E-Commerce Berdasarkan Transformasi Digital Di Indonesia," Jurnal Legislasi Indonesia 16, no. 3 (2019): 392-398.

18 Kamble, "Cyber Law and Information Technology", 789.

19 Mbanaso and Dandaura, "The Cyberspace: Redefining A New World"interact and collaborate with one another. The continuous evolution of components of information and communications technology (ICT, 661 way that such civil rights have been wrongfully impeded in the past, the misuse and misapplication of technology in our society may undermine rights in the new cyberspace. For example, the Center for Digital Society at Universitas Gajah Mada's Faculty of Social and Political Sciences has expressed concerns over diminishing civil rights following the establishment of cyber police in Indonesia, citing both the National Statistics Body and National Human Rights Commission to illustrate the fear of expressing personal opinions online. ${ }^{20}$ Ironically, cyber police intended to combat the cybercrimes previously.

\section{B. Cyber Law in Indonesia}

At first, offenses considered to be cybercrime were handled or prosecuted with the Indonesia Criminal Code (Kitab Undang-Undang Hukum Pidana). Unfortunately, the code was found not to be able to adapt to the evolving crime committed in cyberspace. ${ }^{21}$ This creates an urgency for Indonesia to have a set of regulations that can accommodate activities in cyberspace. The need to regulate cyberspace activities stems from three reasons. First, the need for legal certainty regarding activities committed by perpetrators in cyberspace; Second, to anticipate any implications of the result in the use of information technology; Third, the existence of global variables, such as free trade and open market. ${ }^{22}$

In terms of terminology, there is no definitive universal translation in Indonesian for the term 'cyberlaw.' It is often translated to various terms such as 'Information System Law' (Hukum

20 Center for Digital Society, "The Existence of Indonesia Cyber Police : What Does It Mean for Us Netizens ?," Universitas Gajah Mada's Faculty of Social and Political Sciences, accessed October 20, 2021, https:// cfds.fisipol.ugm.ac.id/2021/02/05/the-existence-ofindonesia-cyber-police-what-does-it-mean-for-usnetizens/\#_edn 11 .

21 Simon Nahak, "Hukum Tindak Pidana Mayantara (Cyber Crime) Dalam Perspektif Akademik," Jurnal Prasada 4, no. 1 (2017): 37-49.

22 Danrivanto Budhijanto, Cyberlaw Dan Revolusi Industri 4.0 - Literasi Digital, ed. Aep Gunarsa, 1st ed. (Bandung: Logoz publishing, 2019), http:// literasidigital.id/books/cyberlaw-dan-revolusiindustri-4-0/., 6 
Sistem Informasi), 'Information Law' (Hukum Informasi), and 'Telecommunication Law' (Hukum Telematika) ${ }^{23}$ However, it is generally acknowledged that cyber law is sui generis, a category that encompasses activities committed in cyberspace, such as privacy issues, the duty of care, procedural issues, and even criminal liability, including but not limited to defamation, theft, and illegal pornography. ${ }^{24}$ It may also encompass commercial or government aspects such as copyrights and trademarks, electronic contracts, digital signatures, electronic commerce, or electronic governments and policy. ${ }^{25}$

The EIT Law was the first law in Indonesia to regulate the activity in cyberspace. The original notion proposing an EIT Law first emerged in the early 2000 s as a response to the legal vacuum regarding cyberspace in the era of President Abdurrahman Wahid. ${ }^{26}$ In the formulation of the EIT Law, the Directorate General of Informatics Application of the Ministry of Communication and Information Technology had analyzed which theory would be the most appropriate as the basis for the law. On the one hand, they considered the instrumental theory, which defines technology as something inherently neutral and independent from economic, political, social, and cultural processes, where the responsibility in using (or misusing) such technology would fall on the people who were utilizing it. The second theory is the substantive theory, defining technology as something that is not neutral and is capable of influencing human interest, with the possibility of that influence being negative. ${ }^{27}$

23 Lita Sari Marita, "Cyber Crime Dan Penerapan Cyber Law Dalam Pemberantasan Cyber Law Di Indonesia," Jurnal Cakrawala 15, no. 2 (2015): 4.

24 Budhijanto, Cyberlaw Dan Revolusi Industri 4.0 Literasi Digital., 3-4.

25 Ibid, 3-4.

26 Yoan Oktaviani, "Kronologi Perjalanan Panjang UU ITE," Kompas, accessed October 20, 2021, https:// kompaspedia.kompas.id/baca/infografik/kronologi/ kronologi-perjalanan-panjang-uu-ite.

27 Radita Setiawan and Muhammad Okky Arista, "Efektivitas Undang-Undang Informasi Dan Transaksi Elektronik Di Indonesia Dalam Aspek Hukum Pidana," Recidive 2, no. 2 (2013): 139-146.
In the end, the EIT Law was built upon a synthesis or hybrid theory, which combines both the instrumental theory and the substantive theory. ${ }^{28}$ The government conducted the drafting for the law in cooperation with several universities that had created their own academic draft that includes Universitas Padjadjaran, Institut Teknologi Bandung, and Universitas Indonesia. The academic draft held the view that the law must at the very least accommodate or regulate the following: $:^{29}$

1. the recognition of documents and electronic information as legal means;

2. the recognition of electronic transactions as equal to non-electronic legal transactions;

3. set a prerequisites standard that shall be met in order for a document or information and electronic transactions to have legal force;

4. regulate matters regarding prohibited acts in the form of misuse of information technology; and

5. regulate extraterritorial issues of jurisdiction.

The EIT Law was officially passed on $21^{\text {st }}$ April 2008. The law is composed of 13 sections and 54 Articles. The content of EIT Law can be divided into two parts. The first part regulates issues regarding e-commerce which includes marketplace, domain names, and electronic signatures. ${ }^{30}$ The second part regulates crimes concerning information technology, including illegal content, illegal access, and data interference. ${ }^{31}$

28 Leski Rizkinaswara, "Menilik Sejarah UU ITE Dalam Tok-Tok Kominfo \#13," Direktorat Jenderal Aplikasi Informatika, accessed April 21, 2021, https://aptika. kominfo.go.id/2019/02/menilik-sejarah-uu-ite-dalamtok-tok-kominfo-13/.

29 Ahmad M Ramli, Naskah Akademik Rancangan Peraturan Pemerintah Tentang Transaksi Elektronik (Badan Pembinaan Hukum Nasional Departemen Hukum dan Hak Asasi Manusia Republik Indonesia, 2005).

30 President of Republic Indonesia, Indonesian Law No. 19 Year 2016 Concerning the Amendment of Law No. 11 Year 2008 on the Electronic Information and Transactions (EIT Law) (Indonesia, 2016).

31 Ibid. 
However, the implementation of the law was not without problems. In 2016, the government decided that the 2008 EIT Law required amendment for several reasons. First, there were objections to Article 27 paragraph (3) regarding defamation and/or insults via the internet, resulting in a constitutional review of the article. Second, there was an objection to the threat of criminal sanctions in Article 45 paragraph (1), which was considered burdensome and disproportionate to the Criminal Code. Third, Article 43 paragraph (3) and paragraph (6) of the EIT Law was considered trouble that law enforcement officials could misuse. Third, there was a constitutional review of Article 31 paragraph (4) regarding the regulation of wiretapping through government regulations. ${ }^{32}$ The accumulation of those reasons above has now resulted in the current and applicable form of Indonesia's EIT Law.

\section{Controversy and Issues}

As previously mentioned, even in light of its amendment in 2016 and again in 2019, the Indonesian EIT law is far from controversy and scrutiny in the public's eyes. While some parties argue that scrutiny may be defended against it, the authors find that certain areas have real and objective causes for concern. Several issues such

32 House of Representatives of the Republic of Indonesia, Perubahan Atas Undang-Undang No. 11 Tahun 2008 Tentang Informasi Dan Transaksi Elektronik (ITE) (Indonesia, 2008).as pesquisas nessa área são fragmentadas, não-cumulativas e raras na literatura. Atualmente, a resistência à Educação a Distância [EAD] é um problema significativo, embora tal tecnologia de ensino tenha elevados índices de crescimento em vários países. $\mathrm{O}$ objetivo desta pesquisa foi identificar e analisar as principais dimensões de resistência à EAD na Educação Corporativa [EC]. Após revisão bibliográfica de temas como EC a Distância, Resistência às Tecnologias e Teoria Unificada de Aceitação e Uso de Tecnologias [UTAUT], foi desenvolvida e testada uma estrutura teórica que visou explicar a Resistência à EAD na EC. As hipóteses iniciais desta pesquisa defenderam que tal resistência","author":[\{“droppi ng-particle":",",'family":"House of Representatives of the Republic of Indonesia","given":,",,"nondropping-particle":",,"parse-names":false,"suffix":" "\}],"id":"ITEM-1","issue":"May",,'issued": \{“dateparts":[[“2008”]]\},"publisher-place":"Indonesia","ti tle":"Perubahan atas Undang-Undang No. 11 Tahun 2008 tentang Informasi dan Transaksi Elektronik (ITE as potential violation of fundamental freedoms, contradiction with other laws, and other things can be observed in several articles within the EIT Law.

\section{a) Defamation and Hate Speech as Criminal Acts under Overly Broad Provisions}

One of the most prominent controversies about the EIT Law is its regulation regarding prohibited acts under Chapter VII. Some people sometimes cite this section as a government tool of oppression. Meanwhile, others said that the conclusion might be presumptive. There are two articles that need special attention: Article 27 (3) on defamation and Article 28(2) on hate speech. The prohibition of online defamation carries criminal charges against "Any person who intentionally and illegally distributes and/ or transmits and/or made accessible Electronic Information and/or Electronic Document which contain offensive and/or defamation content." Offenders face the punishment of up to 4 years and a fine of Rp. 750,000,000. ${ }^{33}$ Meanwhile, the hate speech prohibition threatens "Any Person who intentionally and illegally spreads information intended to cause hatred or hostility to certain individuals and/or certain groups of people based on ethnicity, religion, race, and intergroups (suku, agama, ras, dan antargolongan/ SARA)." It carries a maximum penalty of 6 years imprisonment with Rp. 1,000,000,000 in fines. ${ }^{34}$

Many parties view these two provisions were constructed with overly broad limitations. For example, Aziz Syamsuddin, in his capacity as the Deputy Chairman for the Indonesian House of Representatives (DPR), has spoken for the revision of these articles as they "have been taken out of the law's context to facilitate safe...informationexchange and instead are being used to intimidate innocent factions. ${ }^{35}$ Indonesian non-government

33 President of Republic Indonesia, Indonesian Law No. 19 Year 2016 Concerning the Amendment of Law No. 11 Year 2008 on the Electronic Information and Transactions (EIT Law).

34 Ibid

35 Rofiq Hidayat, "Sejumlah Alasan UU ITE Perlu Diubah Secara Total," Hukum Online, accessed March 15, 2021, https://www.hukumonline.com/berita/baca/ lt6035fff360475/sejumlah-alasan-uu-ite-perlu-diubah- 
coalitions reported that criminal charges under these two articles hold a high conviction rate of $96.8 \%$, with most cases ending in imprisonment sentences. ${ }^{36}$ The most common contributing factor is the Constitutional Court Decision Number 76/ PUU-XV/2017. This decision held that the phrase "between groups (antargolongan)" in Article 28(2) must be interpreted to include "groups" beyond groups of ethnicity, race, and religion. It very much widens the scope of who can lawfully report alleged hate speech. As long as they can find a common factor that unites them as a group, any collection of persons can argue that they fall under the above interpretation of "antargolongan." It can include an endless variety of groups from sexual minorities, activist groups, non-commercial groups to politicians of a particular political party, groups of public officials, or even multiple individuals of a single company or firm.

In addition, there are concerns that journalists and the press suffer from a disproportionate brunt of this issue. The Press Legal Aid Body (Lembaga Bantuan Hukum Pers) asserted that, especially in 2019-2020, those charged under Articles 27(3) and $28(2)$ of the EIT law had been journalists. ${ }^{37}$ Following a statement by the Ministry of Communication and Information Technology's Legal Staff which held the assessment that "criminal provisions in the EIT Law cannot be imposed on the press, as they are protected by the Press Law, ${ }^{\prime 38}$ many have begun asking questions whether the EIT Law conflicts with other laws, particularly concerning journalism and freedom

secara-total.

36 Aji Prasetyo, "Polemik UU ITE, Ini Daftar Pasal Kontroversi," Hukum Online, accessed March 13, 2021, https://www.hukumonline.com/berita/baca/ lt602b902891fcb/polemik-uu-ite--ini-daftar-pasalkontroversi/?page $=1$.

37 Nicholas Ryan Aditya, "Catatan SAFEnet: 8 Kasus Jurnalis Terjerat UU ITE Sepanjang 2019," Kompas, accessed April 22, 2021, https://nasional.kompas.com/ $\mathrm{read} / 2020 / 11 / 14 / 05050021 /$ catatan-safenet--8-kasusjurnalis-terjerat-uu-ite-sepanjang-2019? page=all.

38 Dewan Pers, "Siaran Pers : Ancam Kemerdekaan Pers, UU ITE Perlu Direvisi," Dewan Pers, accessed April 21, 2021, https://dewanpers.or.id/publikasi/siaranpers_ detail/105/Siaran_Pers:_Ancam_Kemerdekaan_Pers, UU_ITE_Perlu_Direvisi. of the press. In order to better describe this problematic phenomenon, this article divides further discussion of Articles 27(3) and 28(2) into the following two sections.

\section{(1) Potential Misuse in Implementation Leading to Violation of Rights}

Before discussing a possible breach or violation of rights caused by the EIT Law's defamation and hate speech provisions, it is important to highlight which rights afforded by law are relevant. In line with the above discussion, the obvious answer will be the right to freedom of expression. Freedom of expression is enshrined in Article 28 and 28E (3) of the Indonesian Constitution and Article 25 of the Indonesian Law Number 39 of 1999 on Human Rights. ${ }^{39}$ The provisions are constructed to protect freedom of expression in the broader sense. Hence, it protects expression in various forms, including internet-based modes of expression such as writing or publication in cyberspace. ${ }^{40}$

It is important to note that this freedom is not without exceptions. For example, article 28J of the Indonesian Constitution carries a limitation to all rights and liberties. They may not impede others' fundamental rights and must satisfy "consideration of morality, religious values, security, and public order." ${ }^{41}$ Furthermore, provisions such as Article 28J should conform to "the Siracusa Principles." The principles, in essence, dictate that a government may only move to restrict certain human rights strictly to the extent of public emergencies as required by the exigencies of the situation. Even today, those restrictions must be made according to standards of legality, evidence-based

39 Republic of Indonesia, Decree of the Consultative Assembly No. XVII/MPR/1998 Concerning Human Rights; Law of the Republic of Indonesia Number 39 Year 1999 on Human Rights, Republic of Indonesia (Indoneisa, 1999).

40 James Boyle, "Foucault in Cyberspace : Surveillance, Sovereignty, and Hardwired Censors," University pf Cincinnati Law Review 66 (1997): 177-205.

41 Republic of Indonesia, The 1945 Constitution of Indonesia. 
necessity, proportionality, and gradualism. ${ }^{42}$ In other words, the Indonesian government is only justified in impeding people's freedom of expression through regulations that are, inter alia, interpreted strictly, non-arbitrary, shall be clear and accessible, and so on so forth.

The problem with Article 27(3) and Article 28(2) of the EIT law is that they do not seem to fulfill the Syracuse Principles' prerequisites. Police seem to be prone to misuse even before a case reaches court. Under Article 21 of the Indonesian Criminal Procedure Code, the investigating police are authorized to detain any individuals without a court-issued warrant for up to a total of 60 days as long as the subjective and objective requirements are evident. The objective requirement is for the penalty for the reported crime to be no less than five years imprisonment, which is met by Article 28(2) and can be met by Article 27(3) should it be reported in conjunction with damages concerning the defamation. The subjective element is also not difficult to meet as law enforcement must only find "circumstances which give rise to concern that the suspect or accused will escape, damage or destroy evidence and/or repeat the offense." The British NGO, Article 19, reported that the accumulation of these factors makes Articles 27(3) and 28(2) of the EIT Law an effective tool of intimidation for parties in power (such as corporations, government parties, or religious majority groups). To silence groups that publicly criticize them, they only need to report to police for up- totwo-month detention. ${ }^{43}$ Public officials have expressed concern that police have also failed to exercise proper discretion in using

42 K. W. Todrys, E. Howe, and J. J Amon, "Failing Siracusa: Governments' Obligations to Find the Least Restrictive Options for Tuberculosis Control," Public Health Action 3, no. 1 (2013).

43 Article 19, Indonesian Report Defending Freedom of Expression and Information (London: Article 19, 2013), https://www.article19.org/data/files/Indonesia_ Report_ENGLISH.pdf. this authority, furthering these provisions' problem. ${ }^{44}$

Scholars have suggested that instead of seeking to remedy hate speech and defamation through criminal law, as has been done in Articles 27(3) and 28(2) EIT, such issues are better resolved through mediation or civil action mechanisms. ${ }^{45}$ This method is considered more effective considering that the form of harm caused by these crimes tends to be about individuals who are personally related to the content being distributed. Therefore, a more accommodating solution to the rehabilitation of the losses suffered by the victim is considered more beneficial to imprisonment. ${ }^{46}$

However, if the government still seeks to establish such acts as criminal, there are still ways to do so without creating such problems as aforementioned. The issue has been resolved in other countries by narrowing such provisions through strict and specific criteria before a suspect can be prosecuted and declared a criminal. Examples of this kind of defamation may be found in Germany, particularly Section 187 of its Criminal Law, which states that "Whoever, against his better judgment, asserts or disseminates an untrue fact in relation to another, which maligns him or disparages him in the public opinion or is capable of endangering his credit, shall be punished with imprisonment for not more than two years or a fine, and, if the act was committed publicly, in a meeting or through the dissemination of writings... with imprisonment for not more than five years or a fine." ${ }^{47}$ Another reference is stipulated

44 CNN Indonesia, “Jokowi: Kalau Picu Ketidakadilan Hapus Pasal Karet UU ITE."

45 Wahyudi Djafar, Lintang Setianti, and Alia Yofira Karunian, Mengembangkan Pendekatan Berbasis HAM Dalam Kebijakan Keamanan Siber:Mencari Distingsi Rezim Keamanan Dan Kejahatan Siber (Jakarta: Lembaga Studi dan Advokasi Masyarakat (ELSAM), 2019), 229.

46 Adami Chazawi, Pelajaran Hukum Pidana, Chapter 1. (Rajawali Per, 2008), 44.

47 Federal Ministry of Justice, Criminal Code in the Version Promulgated on 13 November 1998, Federal Law Gazette, Last Amended by Article 3 of the Law of 2 October 2009, Federal Law Gazette (German, 2010), 
under Section 182(1) of Hungary Criminal Code which states that "The perpetrator may not be punished for the crimes defined in Sections 179 to 181 if the fact suitable for impairing the honor turns out to be true."

(2) Potential Inefficiency and Inconsistency in Legal Recourse Methods

Since journalists and the press seem to suffer most from the implications of the EIT law's overly broad criminal acts provisions, it is also worth looking at the EIT's law's interaction with the Law Number 40 of 1999, which regulates the press ("Press Law"). In part, this law shares the EIT law's goal of preventing false or misleading information and unjustified slander by requiring journalists to conform to the Journalistic Code of Ethics. Among other things, the code obliges the press to produce factual news obtained from clear sources. ${ }^{49}$ Additionally, the Press Law also stipulates people's inherent Right to Response $^{50}$ and their Right to Correct. ${ }^{51}$ The Press Council observes that these rights have developed from what was initially an ethical norm into a legal norm in practice. ${ }^{52}$

However, the Press Law itself acknowledges that complainants against the press are not limited to the right to response nor the right to correct as their only form of legal recourse. Even if a party were to pursue these rights, they are not precluded from reporting the journalists involved for criminal violations, such as Article 18 of the Press law or the previously discussed Article 27(3) or 28(2) EIT law. ${ }^{53}$ This raises additional questions of uniformity in providing legal

http://www.gesetze-im-internet.de/englisch_stgb/. Magyar Kozlony, Act C/2012 the Criminal Code, Criminal and Penal Law (Hungaria, 2012).

49 Republic of Indonesia, Law No. 40 Year 1999 Concerning Press (Press Law); Article 2(d), Journalistic Code of Ethics, No. 03/SK-DP/III/2006, Press Council of Indonesia (Indonesia, 2016).

50 Ibid.

51 Ibid.

52 Dewan Pers, "Mekanisme Penyelesaian Masalah Pemberitaan Pers," Dewan Pers, accessed April 21, 2021, https://dewanpers.or.id/publikasi/opini_ detail/52/Mekanisme_Penyelesaian_Masalah_ Pemberitaan_Pers. recourse for cases involving journalists and parties they have criticized.

This situation depicts a cross-sectional legal implementation which in turn has resulted in inefficiency and inconsistency in practice. It begs the question of whether there should be a more concrete and singular method of legal recourse in handling allegations of defamation and hate speech (such is so prominent under the EIT law) when the press is involved in order to be more consistent, fair, and efficient rulings. For example, if Indonesia were to have a singular judiciary process or body to preside over press integrity, said process or body alone could preside over the content of news reports from the press and create a fairer trial process for members of the press that acknowledges the special status of journalists. There are concrete and successful examples of such single recourse methods, such as in Sweden. The Sweden Press Council comprises a combination of judicial board members (the chair and vice-chairs must all be judges), as well as industry and independent members, and has jurisdiction over printed and online journalism, and those personally affected by a publication can bring a complaint. ${ }^{54}$

\section{b) Problematic Governmental Censorship Powers}

There are various methods in measuring the proportionality of governmental censorship powers. One of which is Gunatilleke's DutyBased Justificatory Approach. This approach highlights the importance of government to demonstrate a sufficient reason for an individual's 'duty of justice,' wherein an individual owes others a duty to refrain from intentional conduct that would cause others harm. ${ }^{55}$ Instead of the

54 "Swedish Freedom of the Press Act" (n.d.), https:// www.riksdagen.se/en/SysSiteAssets/07.-dokument-lagar/the-freedom-of-the-press-act-2015.pdf/.

55 Gehan Gunatilleke, "Justifying Limitations on the Freedom of Expression," Human Rights Review 22, no. 1 (2021): 102.convictions, and beliefs, and to meaningfully participate in democracy. The state may, however, 'limit' the freedom of expression on certain grounds, such as national security, public order, public health, and public morals. Examples 
traditional proportionality test that merely weights the interest between the parties, this approach provides measurements that incorporate public reason and the specific direct responsibility of the individual. ${ }^{56}$ Under this approach, the government

from around the world show that the freedom of individuals to express their opinions, convictions, and beliefs is often imperilled when states are not required to meet a substantial justificatory burden when limiting such freedom. This article critiques one of the common justificatory approaches employed in a number of jurisdictions to frame the state's burden to justify limitations on the freedom of expression- the proportionality test. It presents a case for an alternative approach that builds on the merits and addresses some of the weaknesses of a typical proportionality test. This alternative may be called a 'duty-based' justificatory approach because it requires the state to demonstratethrough the presentation of publicly justifiable reasons - that the individual concerned owes others a duty of justice to refrain from the expressive conduct in question. The article explains how this approach is more normatively compelling than a typical proportionality test. It also illustrates how such an approach can better constrain the state's ability to advance majoritarian interests or offload its positive obligations by limiting the freedom of expression of minorities and dissenting

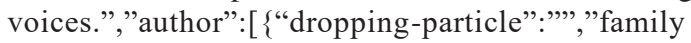
":"Gunatilleke","given":"Gehan","non-droppingparticle":",,",parse-names":false,"suffix":,"”\}],"container-title":"Human Rights Review","id":"'ITEM-1","issue":"1",,issued": \{“date-

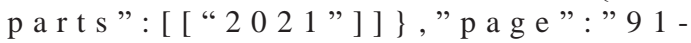
108","publisher":"Human Rights Review","title":"Justifying Limitations on the Freedom of Expression","type":"article-journal" ,"volume":"22", \},"uris":[“http://www.mendeley. com/documents/?uuid=06e8983c-5d27-41bf-ae74416792d4b962"]\}],"mendeley": \{“formattedCitation ":"Gehan Gunatilleke, "Justifying Limitations on the Freedom of Expression," <i>Human Rights Review $<$ । i> 22, no. 1 (2021

56 Ibid.convictions, and beliefs, and to meaningfully participate in democracy. The state may, however, 'limit' the freedom of expression on certain grounds, such as national security, public order, public health, and public morals. Examples from around the world show that the freedom of individuals to express their opinions, convictions, and beliefs is often imperilled when states are not required to meet a substantial justificatory burden when limiting such freedom. This article critiques one of the common justificatory approaches employed in a number of jurisdictions to frame the state's burden to justify limitations on the freedom of expression - the proportionality test. It presents a case for an alternative approach that builds on the merits and addresses some of the weaknesses of a typical proportionality test. This alternative may be called a 'duty-based' justificatory approach because it requires the state to demonstrate - through the could not simply use their censorship powers under the guise of national interest, such as public order, to limit an individual's right, but the government has to demonstrate sufficient reasons to claim the right of the individual concerned.

The following significant issue within the Indonesian EIT law relates to powers of censorship held by the government under the provisions of Article 40(2)(b) in Chapter IX of the law. The law mandates the government to "prevent the spread of prohibited content"; in order to empower it to fulfill this mandate, the government is granted authorization to "terminate access and/or order Electronic System Organizer to terminate the access to Electronic Information and/or Electronic Document containing unlawful contents." [author's emphasis] It is not very surprising that the carrying out of this article has brought even further controversy and concern. The Executive Director of the Institute for Policy Research and Advocacy (ELSAM) went as far as to call this "carrying huge risks of power abuses."

A particularly good example of the misuse of this article was in 2019, where the government used Article 40(2)(b) to justify a three-phase, State-issued mass internet shutdown in Papua

presentation of publicly justifiable reasons - that the individual concerned owes others a duty of justice to refrain from the expressive conduct in question. The article explains how this approach is more normatively compelling than a typical proportionality test. It also illustrates how such an approach can better constrain the state's ability to advance majoritarian interests or offload its positive obligations by limiting the freedom of expression of minorities and dissenting voices.,",author":[\{“dropping-particle":,",,'family ":"Gunatilleke","given":"Gehan",,non-droppingparticle":",","parse-names":false,"suffix":","\}],"container-title":"Human Rights Review","id":’ITEM-1","issue":"1,,,"issued": \{“datepart s" : [ [ “2 $\begin{array}{lllll} & 0 & 2 & 1\end{array}$ ” ] ] , " p a g e " : " 91 108","publisher":"Human Rights Review","title":"Justifying Limitations on the Freedom of Expression","type":"'article-journal" ,"volume":"22" \},"uris":["http://www.mendeley. com/documents/?uuid=06e8983c-5d27-41bf-ae74416792d4b962"]\}],"mendeley": \{“formattedCitation": "Ibid.","plainTextFormattedCitation":"Ibid.","previou slyFormattedCitation":’Ibid."\},"properties": \{“noteIn dex":67\},"schema":"https://github.com/citation-stylelanguage/schema/raw/master/csl-citation.json"\}, 104. 
following anti-racism protests. ${ }^{57}$ These phases started when the government first announced the decision through the press to conduct throttling, which is an act to slow down internet speed in several regions. ${ }^{58}$ It was then followed by the blockage of all internet access in Papua, resulting in increasing riots and the burning of the Telkom Indonesia office in Jayapura. ${ }^{59}$ Finally, this act was eventually lifted gradually from 6 September 2019 to 11 September 2019. ${ }^{60}$

Although the State Administrative Court later ruled this action was unlawful, and beyond the application of Article $40,{ }^{61}$ this serves to illustrate how the provision gives parties in power the entitlement to exercise potentially oppressive suppression and/or censorship against targeted groups.

Even after the State Administrative Court ruling against the case above, concerns regarding the censorship-authority granted by Article 40 (2) (b) still exist and, as we have seen, are not without legitimate reasons. Particularly concerned parties, namely Arnodus Berau and the Alliance of Independent Journalists (AJI), have gone as far as to file a complaint to the Indonesian Constitutional Court. They assert that the article unconstitutionally grants absolute control and monopoly of access to information to the government, who may unilaterally decide what may be accessed by the public. In order to avoid a "likely" abuse of power, they hold the view that the authority must be given to courts instead as they will ensure the due process afforded by

57 Colman Lynch, “Indonesia’s Use of Capital Punishment for Drug-Trafficking Crimes: Legal Obligations, Extralegal Factors, and the Bali Nine Case," Columbia Human Rights Law Review 40, no. 2 (2009): 523-593.

58 CNN Indonesia, "Kronologi Blokir Internet Papua Berujung Vonis Untuk Jokowi," CNN Indonesia, accessed October 20, 2021, https://www.cnnindonesia. com/nasional/20200603150311-20-509478/kronologiblokir-internet-papua-berujung-vonis-untuk-jokowi.

59 Ibid.

60 Ibid

61 Jakarta Administrative, Decision of Indonesian Administrative Court 230/G/TF/2019/PTUN-JKT (Indonesia, 2019).
Indonesian law. ${ }^{62} \mathrm{~A}$ good amount of experts ${ }^{63}$, as well as judges involved in the cases' progress, have called for the government-party to provide transparency of their consideration and process in carrying out content-blocking under Article 40(2) (b). The case is filed as No. 81/PUU-XVIII/2020 and is discussed in further detail in the following section.

Such concerns have not been raised in Indonesia exclusively, as for example, in past years, similar concerns were raised in relation to Iran and Vietnam when they implemented high blocking to independent news sites and a number of social media and communication platforms, suspensions of online newspapers, and content removals activities in ways considered abusive. The recommendations made to them could be adopted by Indonesia to avoid such oppression and governmental abuse of power occurring to its own people: any censorship has to be made according to a formal administrative decision ${ }^{64}$ and in accordance with these three requirements: first, the censorship must target a specific group of people; second, the government cannot be required to implement the censorship policy with specific time; third, the government should open the policymaking process to the public. ${ }^{65}$

62 Constitunional Court of The Republic of Indonesia, Law of the Republic of Indonesia Number 48 Year 2009 Concerning Judicial Authority (Indonesia, 2009).

63 CNN Indonesia, "MK Minta Pemerintah Jelaskan Tahapan Pemblokiran Suara Papua," CNN Indonesia, accessed March 14, 2021, https://www.cnnindonesia. com/nasional/20201117151240-12-570871/mk-mintapemerintah-jelaskan-tahapan-pemblokiran-suarapapua.

64 Constitutional Court of The Republic of Indonesia, Minutes of Case Session No. 81/PUU - XVII/2020 Advising on the Testing of the EIT LAw against the 1945 Constitution Petition Revision Event (Indonesia, 2015).

65 Ahmad Rozali, Aan Suryana, and Safendri Komara Ragamustari, "May 2019 Social Media Censorship in Indonesia: Critical Analysis on The Policy Making Process," Administratio 11, no. 1 (2020): 1-14. 


\section{Review of Cases}

a) Journalist Prosecution under Article 27(3) and 28(2) of Indonesian EIT Law

In order to better illustrate the previous discussion of Article 27(3) and 28(2) of the Indonesian EIT Law being abused by parties' power, the following are two examples of journalists facing such criminal charges under said provisions after being reported by politicians they had criticized. The first example is the case of Muhamad Asrul, a journalist living and working in Palopo, Makassar. In early 2020, he published several articles reporting Farid Karim Judas, the son of Palopo's Mayor Judas Amir, for alleged corruption of public funds. Although Faris had made public clarifications through the legal press mechanisms afforded to him under the Press Law, ${ }^{66}$ Farid still reported Asrul to the police for defamation under Article 28(2) of the EIT Law. The journalist was soon arrested. Although the case did not continue to court, Asrul was held in detention for 36 days. ${ }^{67}$

Another case involves Mohammad Sadli Saleh, a journalist from Central Buton in SouthEast Sulawesi. Saleh had also published an article implying the embezzlement of public funds by Central Buton Mayor, Samahudin in a local media website where he sat as chief of the editorial staff. Prior to this publication, both Saleh and his wife reported that they had been contacted by local government officials, namely from Saleh's wife's place of work at the local Regional Representative Council (DPRD) secretariat, and requested not to publish the article. Following the article being spread on social media, Saleh was arrested, and his wife was dismissed from her job. After months in trial, Saleh was found guilty and sentenced to 2 years in prison in March 2020 of violating Article 27(3) and 28(2) of the EIT law by the District Court of Pasarwarjo, with the judges disregarding

66 Republic of Indonesia, Law No. 40 Year 1999 Concerning Press (Press Law); Article 2(d), Journalistic Code of Ethics, No. 03/SK-DP/III/2006.

67 SAFEnet, "Daftar Kasus Netizen Yang Terjerat UU ITE," Safenet, accessed March 15, 2021, https:// id.safenet.or.id/daftarkasus/. the expert testimony emphasizing the fact that Saleh was a journalist and that the publication was a byproduct of journalism. ${ }^{6}$

It is unfortunate that, while the judges keep to the letter of the law, they have undoubtedly failed to acknowledge the rights of journalists in obtaining and reporting information granted by the Press Law. Additionally, these cases also depicted the uncertain nature of the legal recourse, in that the Right to Response and the Right to Correct that has the potential to resolve the conflict seems to serve no purpose in cases such as Saleh's, against the enforcement of EIT Law's ambiguous provisions on defamation and hate speech.

\section{b) Internet Shutdowns under Article 40(2)(b) of Indonesian EIT Law}

As previously mentioned, one of the landmarks progresses relating to Article 40(2) (b) of the EIT law was the lawsuit filed against the central government following the order of mass internet shutdown in Papua. The order of the President enacted through the Ministry of Communication and Information Technology consisted of three phases that resulted in a total shutdown of the internet in 42 cities and regencies in August and September of 2019. These restrictions, followed by escalations of anti-racism protests that turned into riots, had reportedly led to the death of dozens. The government cited that the shutdown was necessary for preventing the spread of misinformation that might escalate the situation further worsen the situation. However, such a decision inevitably disturbed the people's activities requiring an internet connection, and it inevitably also crippled any news reporting on the incident in the region. Following this, a coalition of several groups filed a lawsuit in the Jakarta State Administrative Court asserting the policy was beyond the permissions granted by Article 40(2)(b) ${ }^{69}$ The Ministry of Communication and

68 Lead Redaction, "Vonis Jurnalis Sadli Preseden Buruk Dan Yurispudensi," LEAD, accessed November 26, 2021, https://www.lead.co.id/vonis-jurnalis-sadlipreseden-buruk-dan-yurispudensi/.

69 Moch. Fiqih Prawira Adjie, "Jokowi 'Violates the Law' for Banning Internet in Papua, Court Declares," The 
Information Technology defended their actions as it was within their attributed authority given by the President, provided that they have also identified, validated, and verified the condition of the conflict at the time with all relevant authorities. ${ }^{70}$ The Court ruled in favor of the claimants, stating the government wrongfully blocked internet access in Papua-West Papua, and the EIT Law only grants the authority to block access to specific electronic information and documents, not the entire internet. In addition, The Court cited the government's failure to provide shreds of evidence that Indonesia was, in whole or in part, under a dangerous situation, as it was, in fact, difficult for the government to assess the situation in Papua due to the poor internet access. ${ }^{71}$ Hence, the internet shutdown was not of proportional measure against the situation in Papua.

The follow up to this case, however, does not end there. As previously discussed, part of the original coalition, namely Arnodus Berau and Alliance of Independent Journalists (AJI), have brought the issue to the Indonesian Constitutional Court, filed as case No. 81/PUUXVIII/2020. They argue that even after the Decision of Jakarta State Administrative Court 230/G/TF/2019/PTUN-JKT, Article 40(2)(b) of EIT Law still provides the government with an unconstitutional right to absolute control and monopoly of access to information that may be used by the government without check. The complainants view that in order to guarantee the right of legal certainty under Article $28 \mathrm{D}(1)$ of the Constitution, there has to be a written decree of a formal administrative decision (Keputusan Tata Usaha Negara) to allow the government to enact their authority afforded by Article 40(2)(b) of EIT Law. ${ }^{72}$ They added that the absence of the decision

Jakarta Post, accessed April 21, 2021, https://www. thejakartapost.com/news/2020/06/03/jokowi-violatesthe-law-for-banning-internet-in-papua-court-declares. html.

70 Jakarta State Administrative Court, Decision of Jakarta State Administrative Court 230/G/TF/2019/PTUN-JKT (Indonesia, 2008).

71 Ibid

72 PTUN Jakarta, Decision of Jakarta State Administrative

would allow the government to perform unlimited rights in conducting another internet shutdown. ${ }^{73}$ The proceedings have called into question the government's considerations and procedure in blocking information under Article 40(2)(b). ${ }^{74}$ The Court rejected the claim, stating that as information often travels fast via the internet, such a process would only prolong the government's action to mitigate any unlawful consequences and to maintain public order. ${ }^{75}$ It is deemed sufficient for the government to simply provide digital notifications to those whose electronic information will be cut off or blocked. ${ }^{76}$

However, the authors would argue that notification is still far from providing a secure and sufficient procedure to allow for governmental censorship. The judges seem to view the interest of the government to 'compete' against the speed of information distribution as more important than the validation and verification of the substances in the information that would be subjected by the censorship itself. There should have been more deliberation and discussion on establishing a procedure that would demonstrate sufficient reasons as the basis for the government to enact a power that would impact citizens' rights.

\section{CONCLUSION}

In conclusion, the EIT Law contains two main problematic issues. First, defamation and hate speech is defined as criminal acts under overly broad provisions in Article 27(3) and 28(2), where its implementation is used by the legal enforcement officials to violate the basic rights of citizens, particularly journalists, against their freedom of expression and freedom of the press. The implementation of this law often leads to wrongful convictions. Second, the problematic governmental censorship power under Article

Court 230/G/TF/2019/PTUN-JKT (Indonesia, 2019).

73

74 Jakarta State Administrative Court, Decision of Jakarta State Administrative Court 230/G/TF/2019/PTUN$J K T$.

75 PTUN Jakarta, Decision of Jakarta State Administrative Court 230/G/TF/2019/PTUN-JKT.

76 Ibid. 
40(2b) has shown probability the abuse of power that governments can use.

Recently, the Ministry of Political, Legal and Security Affairs issued Statement Number 22 of 2021 on the Legal Review Team of EIT Law. It reflects the Indonesian Government's plans to amend the EIT law as a response to the controversial "catch-all articles" within the EIT law. ${ }^{77}$ These steps are expected to narrow provisions containing vague definitions and better facilitate Indonesia's fair and just democracy. In order to avoid any other violations that might result from the implementation of EIT Law, the government should provide more concrete limitations in the EIT Law as recommended, such as looking into the intent and necessity behind alleged defamation and hate speech incidents to avoid wrongful convictions and violations of rights, applying the same exceptions and defenses applicable in general Indonesian criminal law, and further defining the administrative process and reasonable threshold such as the Duty-Based Justificatory Approach, that allows for the government to enact censorship power as clear and transparent as possible to avoid unnecessary response against a conflict.

\section{RECOMMENDATIONS}

Based on the above discussion, the formulation and context of Article 27(3) EIT Law are so broad, vague, and with only limited elucidation, which gives law enforcement officials possibility to misuse this law. To resolve this, the decision to regulate defamation requires the involved legislation to impose more strict and specific criteria Examples of such criteria include the incorporation of phrases such as "an untrue fact which disparage or would potentially disparage a person in the public opinion when committed publicly with intention or negligence." Similar action must be taken for Article 28(2) EIT Law.

Instead of having the State prosecute individuals under Articles 27(3) and 28(2), The

77 Coordinator Minisistry of Politic Law and Security, Decision of Indonesian Constitutional Court No. 81/ PUU-XVIII/2020 (Indonesia, 2021). authors also wish to echo the scholar's position that believes the case of hate speech and defamation to be resolved by mediation and/or civil law. It will allow for a restorative remedy while minimizing the margin for injustice.

Additionally, the authors recommend solving the inefficient status quo of multiple legal recourses against potentially false press coverage in Indonesia by having a single judiciary process or body to preside over press integrity. The proposed single process or body alone will preside over the content of news reports from the press, create a fairer trial process for members of the press that acknowledges the special status of journalists.

Regarding the problematic governmental censorship, the authors recommend that any censorship must be made according to a formal administrative decision ${ }^{78}$. In order to avoid governmental abuse of power, there are some efforts should be made. First, censorship must target a specific group of people. Second, the government cannot be required to implement the censorship policy at a specific time. Third, the government should open the policymaking process to the public. ${ }^{79}$

\section{ACKNOWLEDGEMENTS}

The authors would like to thank Dr. Idris, S.H., M.A. as the dean of the Faculty of Law, Universitas Padjadjaran, for all the support given during the process of writing this article.

\section{BIBLIOGRAPHY}

Aditya, Nicholas Ryan. "Catatan SAFEnet: 8 Kasus Jurnalis Terjerat UU ITE Sepanjang 2019." Kompas. Accessed April 22, 2021. https://nasional.kompas.com/ $\mathrm{read} / 2020 / 11 / 14 / 05050021 / \mathrm{catatan}$-safenet-8-kasus-jurnalis-terjerat-uu-ite-sepanjang2019? page $=$ all.

78 Constitutional Court of The Republic of Indonesia, Minutes of Case Session No. 81/PUU - XVII/2020 Advising on the Testing of the EIT LAw against the 1945 Constitution Petition Revision Event.

79 Rozali, Suryana, and Ragamustari, "May 2019 Social Media Censorship in Indonesia : Critical Analysis on The Policy Making Process.” 
Ahmad M. Ramli. Hukum Telematika. Open University. Banten: Open University, 2020.

Amiruddin, and Zainal Asikin. Pengantar Metode Penelitian Hukum. Revisi. Jakarta: Raja Grafindo Persada, 2018.

Article 19. Indonesian Report Defending Freedom of Expression and Information. London: Article 19, 2013. https://www.article19.org/ data/files/Indonesia_Report_ENGLISH.pdf.

Boyle, James. "Foucault in Cyberspace : Surveillance, Sovereignty, and Hardwired Censors." University pf Cincinnati Law Review 66 (1997): 177-205.

Budhijanto, Danrivanto. Cyberlaw Dan Revolusi Industri 4.0 - Literasi Digital. Edited by Aep Gunarsa. 1st ed. Bandung: Logoz publishing, 2019. http://literasidigital.id/ books/cyberlaw-dan-revolusi-industri-4-0/.

Center for Digital Society. "The Existence of Indonesia Cyber Police : What Does It Mean for Us Netizens ?" Universitas Gajah Mada's Faculty of Social and Political Sciences. Accessed October 20, 2021. https://cfds. fisipol.ugm.ac.id/2021/02/05/the-existenceof-indonesia-cyber-police-what-does-itmean-for-us-netizens/\#_edn11.

Chazawi, Adami. Pelajaran Hukum Pidana. Chapter 1. Rajawali Per, 2008.

CNN Indonesia. "Jokowi: Kalau Picu Ketidakadilan Hapus Pasal Karet UU ITE." CNN Indonesia. Accessed April 20, 2021. https://www.cnnindonesia.com/ nasional/20210216092243-32-606711/ jokowi-kalau-picu-ketidakadilan-hapuspasal-karet-uu-ite.

—. "Kronologi Blokir Internet Papua Berujung Vonis Untuk Jokowi." CNN Indonesia. Accessed October 20, 2021. https://www.cnnindonesia.com/ nasional/20200603150311-20-509478/ kronologi-blokir-internet-papua-berujungvonis-untuk-jokowi.

-. "MK Minta Pemerintah Jelaskan Tahapan Pemblokiran Suara Papua." CNN Indonesia. Accessed March 14, 2021. https://www.cnnindonesia.com/ nasional/20201117151240-12-570871/ mk-minta-pemerintah-jelaskan-tahapanpemblokiran-suara-papua.

Constitunional Court of The Republic of Indonesia. Law of the Republic of Indonesia Number 48 Year 2009 Concerning Judicial Authority. Indonesia, 2009.

Constitutional Court of The Republic of Indonesia. Minutes of Case Session No. 81/PUU XVII/2020 Advising on the Testing of the EIT LAw against the 1945 Constitution Petition Revision Event. Indonesia, 2015.

Coordinator Minisistry of Politic Law and Security. Decision of Indonesian Constitutional Court No. 81/PUU-XVIII/2020. Indonesia, 2021.

Dewan Pers. "Mekanisme Penyelesaian Masalah Pemberitaan Pers." Dewan Pers.. Accessed April 21, 2021. https://dewanpers.or.id/ publikasi/opini_detail/52/Mekanisme_ Penyelesaian_Masalah_Pemberitaan_Pers.

- "Siaran Pers : Ancam Kemerdekaan Pers , UU ITE Perlu Direvisi." Dewan Pers. Accessed April 21, 2021. https://dewanpers. or.id/publikasi/siaranpers_detail/105/ Siaran_Pers:_Ancam_Kemerdekaan_Pers, UU_ITE_Perlu_Direvisi.

Djafar, Wahyudi, Lintang Setianti, and Alia Yofira Karunian. Mengembangkan Pendekatan Berbasis HAM Dalam Kebijakan Keamanan Siber:Mencari Distingsi Rezim Keamanan Dan Kejahatan Siber. Jakarta: Lembaga Studi dan Advokasi Masyarakat (ELSAM), 2019.

ELSAM Team. Buku Saku Kebebasan Berekspresi Di Internet. Seri Internet Dan HAM. Jakarta Selatan: Lembaga Studi dan Advokasi Masyarakat [ELSAM], n.d. file:///C:/Users/ User/Downloads/fvm939e.pdf.

Federal Ministry of Justice. Criminal Code in the Version Promulgated on 13 November 1998, Federal Law Gazette, Last Amended by Article 3 of the Law of 2 October 2009, Federal Law Gazette. German, 2010. http:// www.gesetze-im-internet.de/englisch_stgb/.

Freedom House. "Freedom on the Net 2018: Indonesia." Freedom House. Accessed November 26,2021. https://freedomhouse. org/report/freedom-net/freedom-net-2018. 
German Government. "Cyber Security Strategy for Germany." Federal Ministry of the Interior. Accessed May 8, 2021. http://www. cio.bund.de/SharedDocs/Publikationen/DE/ Strategische-Themen/css_engl_download. pdf? blobpublicationFile.

Gunatilleke, Gehan. "Justifying Limitations on the Freedom of Expression." Human Rights Review 22, no. 1 (2021): 91-108.

Hidayat, Rofiq. "Sejumlah Alasan UU ITE Perlu Diubah Secara Total." Hukum Online. Accessed March 15, 2021. https:// www.hukumonline.com/berita/baca/ lt6035fff360475/sejumlah-alasan-uu-iteperlu-diubah-secara-total.

House of Representatives of the Republic of Indonesia. Perubahan Atas Undang-Undang No. 11 Tahun 2008 Tentang Informasi Dan Transaksi Elektronik (ITE). Indonesia, 2008.

Inter-American Commission On Human Right. Freedom of Expression and the Internet. Finland: Organization of American States, 2013.

Inter-American Commission on Human Rights. Special Rapporteur on Freedom of Expression, 2013.

Internet World Stats. "World Internet Usage and Population Statistics 2021 Year-Q1 Estimates." Internet World Stats. Accessed March 15, 2021. https://www. internetworldstats.com/stats.htm.

Jakarta Administrative. Decision of Indonesian Administrative Court 230/G/TF/2019/ PTUN-JKT. Indonesia, 2019.

Jakarta State Administrative Court. Decision of Jakarta State Administrative Court 230/G/ TF/2019/PTUN-JKT. Indonesia, 2008.

Kamble, R M. "Cyber Law and Information Technology." International Journal of Scientific \& Engineering Research 4, no. 5 (2013): 789-794. http://www.ijser.org.

Kompas. "Sidang Uji Materi UU ITE , Ahli Nilai Pihak Penentu Konten Internet Bermuatan Negatif Tak Jelas." Kompas. Accessed March 13, 2021. https://nasional.kompas. com/read/2020/12/15/16591191/sidang uji-materi-uu-ite-ahli-nilai-pihak-penentu- konten-internet-bermuatan.

Kosseff, Jeff. "Defining Cybersecurity Law." Iowa Law Review 103, no. 3 (2018): 985-1031.

Lead Redaction. "Vonis Jurnalis Sadli Preseden Buruk Dan Yurispudensi." LEAD. Accessed November 26, 2021. https://www.lead.co.id/ vonis-jurnalis-sadli-preseden-buruk-danyurispudensi/.

Lynch, Colman. "Indonesia's Use of Capital Punishment for Drug-Trafficking Crimes: Legal Obligations, Extralegal Factors, and the Bali Nine Case." Columbia Human Rights Law Review 40, no. 2 (2009): 523-593.

Magyar Kozlony. Act C/2012 the Criminal Code, Criminal and Penal Law. Hungaria, 2012.

Marita, Lita Sari. "Cyber Crime Dan Penerapan Cyber Law Dalam Pemberantasan Cyber Law Di Indonesia." Jurnal Cakrawala 15, no. 2 (2015): 4.

Marwadianto, Marwadianto. "Hak Atas Kebebasan Berpendapat Dan Berekspresi." Jurnal HAM 11, no. 1 (2020): 1-4. https:// ejournal.balitbangham.go.id/index.php/ham/ article/view/976/pdf.

Mbanaso, U M, and E S Dandaura. "The Cyberspace: Redefining A New World." IOSR Journal of Computer Engineering 17, no. 3 (2015): 2278-661. www.iosrjournals. org.

Nahak, Simon. "Hukum Tindak Pidana Mayantara (Cyber Crime) Dalam Perspektif Akademik." Jurnal Prasada 4, no. 1 (2017): 37-49.

Oktaviani, Yoan. "Kronologi Perjalanan Panjang UU ITE.” Kompas. Accessed October 20, 2021. https://kompaspedia.kompas.id/baca/ infografik/kronologi/kronologi-perjalananpanjang-uu-ite.

OSCE. Joint Declarations of the Representatives of Intergovernmental Bodies to Protect Free Media and Expression. Edited by Adeline Hulin. Vienna: OSCE The Representative on Freedom of the Media, 2013.

Prasetyo, Aji. "Polemik UU ITE, Ini Daftar Pasal Kontroversi." Hukum Online. Accessed March 13, 2021. https://www.hukumonline. com/berita/baca/lt602b902891fcb/polemikuu-ite--ini-daftar-pasal-kontroversi/?page=1. 
Prawira Adjie, Moch. Fiqih. "Jokowi 'Violates the Law' for Banning Internet in Papua, Court Declares." The Jakarta Post. Accessed April 21, 2021. https://www.thejakartapost. com/news/2020/06/03/jokowi-violates-thelaw-for-banning-internet-in-papua-courtdeclares.html.

President of Republic Indonesia. Indonesian Law No. 19 Year 2016 Concerning the Amendment of Law No. 11 Year 2008 on the Electronic Information and Transactions (EIT Law). Indonesia, 2016.

- Law of the Republic of Indonesia Number 8 Year 1981 on The Law of Criminal Procedure (Indonesian Criminal Procedure Code). Indonesia, 1981.

PTUN Jakarta. Decision of Jakarta State Administrative Court 230/G/TF/2019/ PTUN-JKT. Indonesia, 2019.

Ramli, Ahmad M. Naskah Akademik Rancangan Peraturan Pemerintah Tentang Transaksi Elektronik. Badan Pembinaan Hukum Nasional Departemen Hukum dan Hak Asasi Manusia Republik Indonesia, 2005.

Ramli, Tasya Safiranita, Ahmad M Ramli, Danrivanto Budhijanto, Rika Ratna Permata, Huala Adolf, Eddy Damian, and Miiranda Risang Ayu Palar. "Prinsip-Prinsip Cyber Law Pada Media Over The Top E-Commerce Berdasarkan Transformasi Digital Di Indonesia." Jurnal Legislasi Indonesia 16, no. 3 (2019): 392-398.

Reed, Kristin, and Ausra Padskocimaite. The Right Toolkit: Applying Research Methods in the Service of Human Rights. human rights center university of california, Berkeley school of law, 2012.

Republic of Indonesia. Decree of the Consultative Assembly No. XVII/MPR/1998 Concerning Human Rights; Law of the Republic of Indonesia Number 39 Year 1999 on Human Rights. Republic of Indonesia. Indoneisa, 1999.

. Law No. 40 Year 1999 Concerning Press (Press Law); Article 2(d), Journalistic Code of Ethics, No. 03/SK-DP/III/2006. Press Council of Indonesia. Indonesia, 2016.
The 1945 Constitution of Indonesia. Indonesia, 2002. http://luk.tsipil.ugm.ac.id/ atur/UUD1945.pdf.

Rizkinaswara, Leski. "Menilik Sejarah UU ITE Dalam Tok-Tok Kominfo \#13." Direktorat Jenderal Aplikasi Informatika. Accessed April 21, 2021. https://aptika.kominfo. go.id/2019/02/menilik-sejarah-uu-ite-dalamtok-tok-kominfo-13/.

Rozali, Ahmad, Aan Suryana, and Safendri Komara Ragamustari. "May 2019 Social Media Censorship in Indonesia : Critical Analysis on The Policy Making Process." Administratio 11, no. 1 (2020): 1-14.

SAFEnet. "Daftar Kasus Netizen Yang Terjerat UU ITE.” Safenet. Accessed March 15, 2021. https://id.safenet.or.id/daftarkasus/.

Saraswati, Anak Agung Ayu Nanda. "The Need To Protect Freedom Of Expression On The Internet Through A Human Rights-Based In." ASEAN Journal of Legal Studies 2, no. 1 (2019): 54-69.

Setiawan, Radita, and Muhammad Okky Arista. "Efektivitas Undang-Undang Informasi Dan Transaksi Elektronik Di Indonesia Dalam Aspek Hukum Pidana." Recidive 2, no. 2 (2013): 139-146.

Sunggono, Bambang. Metodologi Penelitian Hukum. Cetakan ke. Jakarta: Rajawali Pers, 2015.

Sutrisno, Nandang. "Cyberlaw: Problem Dan Prospek Pengaturan Aktivitas Internet." Jurnal Hukum IUS QUIA IUSTUM 8, no. 16 (2001): 30-41.

The Jakarta Post. "Revised ITE Law Could Hamper Freedom of Expression: Researcher." The Jakarta Post. Accessed March 11, 2021. https://www.thejakartapost.com/ news/2016/10/31/revised-ite-law-couldhamper-freedom-of-expression-researcher. html.

Todrys, K. W., E. Howe, and J. J Amon. "Failing Siracusa: Governments' Obligations to Find the Least Restrictive Options for Tuberculosis Control." Public Health Action 3, no. 1 (2013). 
United Nations General Assembly. "Report of the Special Rapporteur on the Promotion and Protection of the Right to Freedom of Opinion and Expression." Human Rights Council 17, no. 27 (2011): 4-22.

Went, Robert. "Globalization: Myths, Reality, and Ideology." Journal of Political Economy 26, no. 3 (1997): 39-59.

Wiener, Nobert. Cybernetics: Or Control and Communication in the Animal and the Machine. The Massachusetts Institute of Technology. Second. Vol. 56. Cambridge: The MIT Press, 1948.

World Bank. "Individuals Using the Internet (\% of Population) - Indonesia." The World Bank. Accessed November 26, 2021. https://data. worldbank.org/indicator/IT.NET.USER. $\mathrm{ZS}$ ?locations $=\mathrm{VN}$.

"Swedish Freedom of the Press Act" (n.d.). https:// www.riksdagen.se/en/SysSiteAssets/07.dokument--lagar/the-freedom-of-the-pressact-2015.pdf/. 
HALAMAN KOSONG 